\title{
The Impact of COVID-19 Lockdowns on Satellite-Observed Aerosol Optical Thickness over the Surrounding Coastal Oceanic Areas of Megacities in the Coastal Zone
}

\author{
Kai Wang ${ }^{1}$ and Xuepeng Zhao ${ }^{2, *(D)}$ \\ 1 Thomas Jefferson High School for Science and Technology, 6560 Braddock Rd., Alexandria, VA 22312, USA; \\ 2024kwang@tjhsst.edu \\ 2 National Centers for Environmental Information (NCEI), NOAA/NESDIS, Silver Spring, MD 20910, USA \\ * Correspondence: Xuepeng.Zhao@noaa.gov
}

Citation: Wang, K.; Zhao, X. The Impact of COVID-19 Lockdowns on Satellite-Observed Aerosol Optical Thickness over the Surrounding Coastal Oceanic Areas of Megacities in the Coastal Zone. Geographies 2021, 1, 381-397. https://doi.org/10.3390/ geographies1030021

Academic Editor: Adriano Ribolini

Received: 5 November 2021

Accepted: 16 December 2021

Published: 18 December 2021

Publisher's Note: MDPI stays neutral with regard to jurisdictional claims in published maps and institutional affiliations.

Copyright: (c) 2021 by the authors. Licensee MDPI, Basel, Switzerland. This article is an open access article distributed under the terms and conditions of the Creative Commons Attribution (CC BY) license (https:// creativecommons.org/licenses/by/ $4.0 /)$.

\begin{abstract}
Nearly 40 years of aerosol optical thickness (AOT) climate data record (CDR) derived from NOAA operational satellite Advanced Very High Resolution Radiometer (AVHRR) observation over the global oceans is used to study the AOT changes due to the COVID-19 lockdown over the surrounding coastal oceanic areas of 18 megacities in the coast zone (MCCZ). The AOT difference between the annual mean AOT values of 2020 with COVID-19 lockdown and 2019 without the lockdown along with the 2020 AOT annual anomaly are used to effectively identify the AOT changes that are a result of the lockdown. We found that for most of the $18 \mathrm{MCCZ}$, the COVID-19 lockdowns implemented to contain the spread of the coronavirus resulted in a decrease between $1 \%$ and $30 \%$ in AOT due to reduced anthropogenic emissions associated with the lockdowns. However, the AOT long-term trend and other aerosol interannual variations due to favorable or unfavorable meteorological conditions may mask AOT changes due to the lockdown effect in some MCCZ. Different seasonal variations of aerosol amount in 2020 relative to 2019 due to other natural aerosol emission sources not influenced by the lockdown, such as dust storms and natural biomass burning and smoke, may also conceal a limited reduction in the annual mean AOT due to the lockdown in MCCZ with relatively loose lockdown. This study indicates that the use of long-term satellite observation is helpful for studying and monitoring the aerosol changes due to the emission reduction associated with the COVID-19 lockdown in the surrounding coastal oceanic areas of MCCZ, which will benefit the future development of the mitigation strategy for air pollution and emissions in megacities.
\end{abstract}

Keywords: COVID-19; lockdown; aerosol; satellite; air quality

\section{Introduction}

The coronavirus disease 2019 (COVID-19) pandemic, which affects the whole world, began in 2020 and has continued into 2021, causing a global public health and human life disaster that is unprecedented in this century [1,2]. Megacities, which are large and densely populated, have been the most heavily stricken regions of the COVID-19 pandemic. To effectively contain the spread of the coronavirus, confinement polices of varying stringency and extent have been implemented in affected cities, regions, and countries. Unintentionally, pollution emissions associated with anthropogenic activities were reduced in these cities during the lockdown periods [3-6]. As a result, air quality in urban and ambient suburban areas of these cities was also altered unexpectedly to a different extent [7-14], especially in the megacities, which are normally influenced by heavy anthropogenic pollution due to active human activities (e.g., construction, transportation, energy generation, industrial production, and others) and pollution can be transported hundreds and even thousands of miles away under favorable meteorological conditions [15-19]. Here, we define a megacity as a large urban agglomeration with a population exceeding 10 million inhabitants. The majority of these urban megacities are located in a coastal zone or a zone 
with a distinct coastal influence [20], and are called Mega Cities in the Coastal Zone (MCCZ) hereafter. The reduction in pollution emission during the pandemic lockdown periods of these MCCZ provides us with a unique opportunity to study in a natural condition the impact of surface emissions on air quality during the lockdown period relative to the "business-as-usual" pollution period. The results of this study will assist in finding mitigation strategies for air pollution emissions in MCCZ, because air pollution is one of the most imminent environmental issues faced by MCCZ in recent decades $[15,17,21,22]$, especially in developing countries where limited resources are available to address pollution issues.

Air pollution originated from MCCZ may extend hundreds or even thousands of kilometers to the downwind oceanic regions in the atmosphere [16,20,23-25]. One of the most important ambient air pollutants is particulate matter (PM) or atmospheric aerosolstiny pieces of solid or liquid particles suspended in the air. Atmospheric aerosols in an urban environment cause serious air quality and health issues. In addition, they are cooling and warming agents for climate change because they scatter and absorb solar and earth radiation $[25,26]$ and serve as cloud condensation nuclei (CCN) $[27,28]$. Aerosol optical thickness (AOT) has been used to estimate PM amount for urban air pollution $[29,30]$. This is because a high or low AOT value corresponds to a high or low PM amount, assuming most of the aerosols are near ground or in the planetary boundary layer (PBL) of an urban environment. This assumption is valid in most of the time when local pollution is dominant compared to advected pollution originated from outside of a big city [31]. Thus, long-term satellite observation of AOT over MCCZ and their surrounding areas may provide information about the changes and trends of air pollution, including the impact of COVID-19 lockdown on AOT changes.

In this paper, we analyze AOT and its changes around MCCZ observed in 2020 with the pandemic lockdown relative to 2019 pre-lockdown as well as relative to the annual climatology of the past four decades. The long-term AOT data record is derived from the observation of Advanced Very High Resolution Radiometer (AVHRR) onboard the polar operational satellites of National Ocean and Atmospheric Administration (NOAA).

\section{Materials and Methods}

\subsection{Selected MCCZ and Data Used}

\subsubsection{MCCZ}

Eighteen urban centers in the coastal zone with inhabitants exceeding 10 million were selected as MCCZ in our current study. These MCCZ have been profoundly affected by the COVID-19 pandemic in 2020, in part due to the lockdown measures implemented either fully or partially to slow the transmission of coronavirus and reduce the rate of infection. During the lockdown period, air quality of these MCCZ was altered to varying degrees. Table 1 summarizes the period of major partial or full lockdowns in 2020 for the 18 selected MCCZ along with their location (latitude/longitude) and population. Aside from the relatively long major lockdown period, several short-term lockdowns were enforced during 2020 in most of the $18 \mathrm{MCCZ}$ to control the surge of the infection after the relaxion of the major lockdown.

Figure 1 shows the population (based on data from Wikipedia; https:/ / en.wikipedia. org / wiki/Main_Page, accessed on 3 November 2021) along with the AOT annual mean climatology and its long-term (1982-2019) linear changing trend derived from the NOAA satellite AVHRR AOT climate data record (CDR) for the $18 \mathrm{MCCZ}$. AOT on $0.63-\mu \mathrm{m}$ wavelength is computed for a square window sized $\pm 2^{\circ}$ latitude and longitude around the individual MCCZ with the city center in the middle. The selection of this studying domain was based on the sensitivity analysis on the three sets of widow size $\left( \pm 1^{\circ}, \pm 2^{\circ}\right.$, and $\left.\pm 4^{\circ}\right)$ in consideration of having sufficient observational AOT samples to compute monthly mean AOT for all of $18 \mathrm{MCCZ}$ as well as still retaining the influence of urban emission in the domain average of monthly mean AOT values. Specifically, we set a threshold that the grid points in the selected square domain around each MCCZ should at least have $10 \%$ over ocean, which is 160 grid points for the $4^{\circ} \times 4^{\circ}$ square domain since the spatial resolution 
of monthly AOT CDR product is $0.1^{\circ} \times 0.1^{\circ}$. For the grid points over ocean in a square domain, we set another threshold that at least $50 \%$ of them should have all of 12 monthly AOT values for each year in order to be used for computing annual mean AOT utilized in our analysis for the square domain. Thus, there are at least 80 grid points for the $4^{\circ} \times 4^{\circ}$ square domain have monthly AOT values for each year, which are used to compute domain averaged annual mean AOT for each MCCZ.

Table 1. The major period of partial or full lockdown in 2020 for eighteen selected MCCZ along with their location (latitude/longitude) and population (million).

\begin{tabular}{|c|c|c|c|c|c|c|}
\hline$\#$ & MCCZ & $\begin{array}{l}\text { Latitude } \\
\text { (Degree) }\end{array}$ & $\begin{array}{l}\text { Longitude } \\
\text { (Degree) }\end{array}$ & $\begin{array}{l}\text { Population } \\
\text { (Million)* }\end{array}$ & $\begin{array}{l}\text { Lockdown Period of } \\
2020(\mathrm{~mm} . d \mathrm{~d}-\mathrm{mm} . \mathrm{dd})\end{array}$ & Note \\
\hline 1 & Tokyo & 35.5762 & 139.6503 & 34.4 & $02.20-05.14$ & $\begin{array}{l}\text { [6] Torkmahalleh et al., AAQR, } \\
\text { https:// doi.org/10.4209/aaqr.200567, } \\
\text { accessed on } 2 \text { August } 2021\end{array}$ \\
\hline 2 & Shanghai & 31.2304 & 121.4737 & 24.3 & $01.23-04.08$ & The same as \#1 \\
\hline 3 & Sao Paulo & -23.5505 & -46.6333 & 21.6 & 03.17-Continued ** & The same as \#1 \\
\hline 4 & Mumbai & 19.076 & 72.8777 & 20.6 & $03.24-05.31$ & $\begin{array}{l}\text { [32] Kumari et al., AAQR, https: } \\
\text { // doi.org/10.4209/aaqr.2020.05.0262, } \\
\text { accessed on } 29 \text { September } 2020\end{array}$ \\
\hline 5 & New York & 40.7128 & -74.006 & 20.3 & $03.16-4.24$ & The same as \#1 \\
\hline 6 & Osaka-Kobe & 34.6937 & 135.5023 & 19.3 & $02.20-05.14$ & The same as \#1 \\
\hline 7 & Buenos Aires & -34.6037 & -58.3816 & 15.6 & 03.19-07.17 & $\begin{array}{l}\text { Wikipedia (https://en.wikipedia.org/ } \\
\text { wiki/COVID-19_pandemic_in_Argentina, } \\
\text { accessed on } 3 \text { November 2021) }\end{array}$ \\
\hline 8 & Istanbul & 41.0082 & 28.9784 & 15.5 & $03.04-05.10$ & The same as \#1 \\
\hline 9 & Karachi & 24.8607 & 67.0011 & 14.9 & $03.24-04.15$ & $\begin{array}{l}\text { [33] Sipra et al., AAQR, https: } \\
\text { / / doi.org/10.4209/aaqr.2020.07.0459, } \\
\text { accessed on 13 October } 2020\end{array}$ \\
\hline 10 & Kolkata & 22.5726 & 88.3639 & 14.8 & $03.19-04.25$ & The same as \#1 \\
\hline 11 & Lagos & 6.5244 & 3.3792 & 14.4 & 03.30-05.04 & $\begin{array}{l}\text { [34] Lanre Ibrahim et al., Health Policy } \\
\text { Technol., doi: } 10.1016 / \text { j.hlpt.2020.09.004, } \\
\text { accessed on } 15 \text { September } 2020 .\end{array}$ \\
\hline 12 & Los Angeles & 34.0522 & -118.2437 & 13.1 & $03.16-5.18$ & $\begin{array}{l}\text { https:/ / www.nbclosangeles.com/news/ } \\
\text { coronavirus/california-coronavirus- } \\
\text { pandemic-timeline-key-events/2334100/, } \\
\text { accessed on } 3 \text { November } 2021\end{array}$ \\
\hline 13 & Manila & 14.5995 & 120.9842 & 12.9 & 03.14-Continued & $\begin{array}{l}\text { Wikipedia (https: } \\
\text { //en.wikipedia.org/wiki/Enhanced__ } \\
\text { community_quarantine_in_Luzon, } \\
\text { accessed on } 3 \text { November 2021) }\end{array}$ \\
\hline 14 & Shenzhen & 22.5431 & 114.0579 & 12.5 & $01.23-04.08$ & The same as \#1 \\
\hline 15 & Tianjin & 39.3434 & 117.3616 & 12.5 & $01.23-04.08$ & The same as \#1 \\
\hline 16 & Rio de Janeiro & -22.9068 & -43.1729 & 12.3 & 03.17-Continued & The same as \#1 \\
\hline 17 & Jakarta & 6.2088 & 106.8456 & 10.8 & 03.15-Early June & The same as \#1 \\
\hline 18 & Lima & -12.0464 & -77.0428 & 10.1 & 03.16-Continued & The same as \#1 \\
\hline
\end{tabular}

* Population is from Wikipedia (https://en.wikipedia.org/wiki/Main_Page, accessed on 3 November 2021). ** "continued" means the city continued partial or loosened closure measures after the major tight lockdown period. 


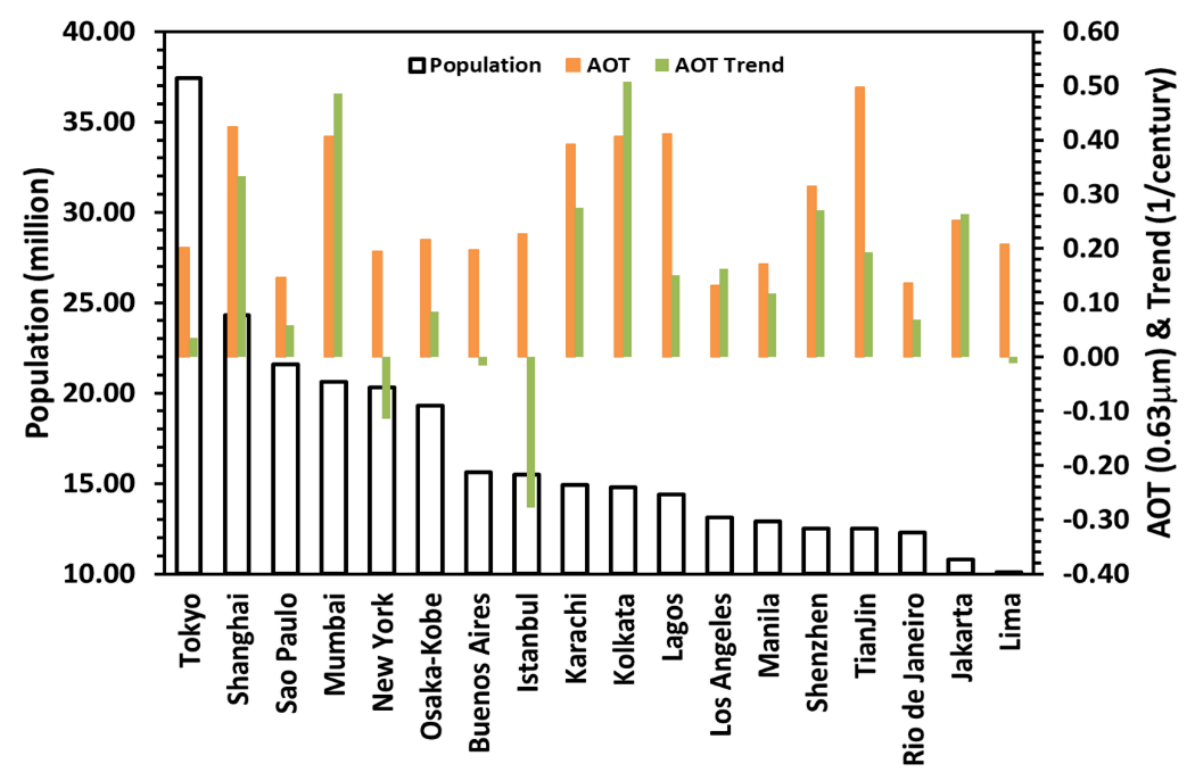

Figure 1. Eighteen selected megacities in the coastal zone (MCCZ) in our study and their population, long-term mean AOT on 0.63- $\mu \mathrm{m}$ wavelength, and AOT linear long-term trend, respectively.

Among these megacities, there are five (Tokyo, Osaka-Kobe, New York, Los Angeles, and Istanbul) in developed countries with relatively small AOT. AOT long-term trends in New York and Istanbul are negative but are positive in the other three megacities. The remaining thirteen $\mathrm{MCCZ}$ are in developing countries. There are five (Sao Paulo, Rio de Janeiro, Buenos Aires, Lima, and Jakarta) in the Southern Hemisphere (SH) with relatively small AOT. Positive AOT long-term changing trends are noted in Sao Paulo, Rio de Janeiro, and Jakarta while small negative AOT trends are seen in Buenos Aires and Lima. The other MCCZ are in the Northern Hemisphere (NH) and have relatively large aerosol loading, especially the megacities in China and India (e.g., Shanghai, Tianjin, Mumbai, and Kolkata), where positive AOT long-term changing trends are evident. Fifteen out of the 18 megacities are in the coastal zone of tropical or subtropical regions and the other three (New York, Tianjin, and Istanbul) are on the coasts of the $\mathrm{NH}$ temperate zone.

Figure 2 shows the global map of temporally (1982-2019) averaged AVHRR AOT on $0.63-\mu \mathrm{m}$ wavelength (called AOT climatology) as well as the locations of $18 \mathrm{MCCZ}$ (marked by red square boxes). The boxes with a size of $\pm 2^{\circ}$ longitude/latitude around the $\mathrm{MCCZ}$ are used to compute the AOT values for the $18 \mathrm{MCCZ}$. The AOT values over the coastal oceanic surface around these MCCZ are generally higher than those over downwind remote ocean surface due to the offshore transport of aerosols that originated from urban pollutions. Thus, the changes of AOT due to considerable emission enhancement as well as reduction events in urban and suburban areas of these MCCZ may extend over the coastal ocean around the MCCZ. Therefore, satellite-observed AOT can be used to monitor the variation and changing tendency of aerosol amount around these MCCZ caused by emission change, such as that due to the COVID-19 lockdowns. 


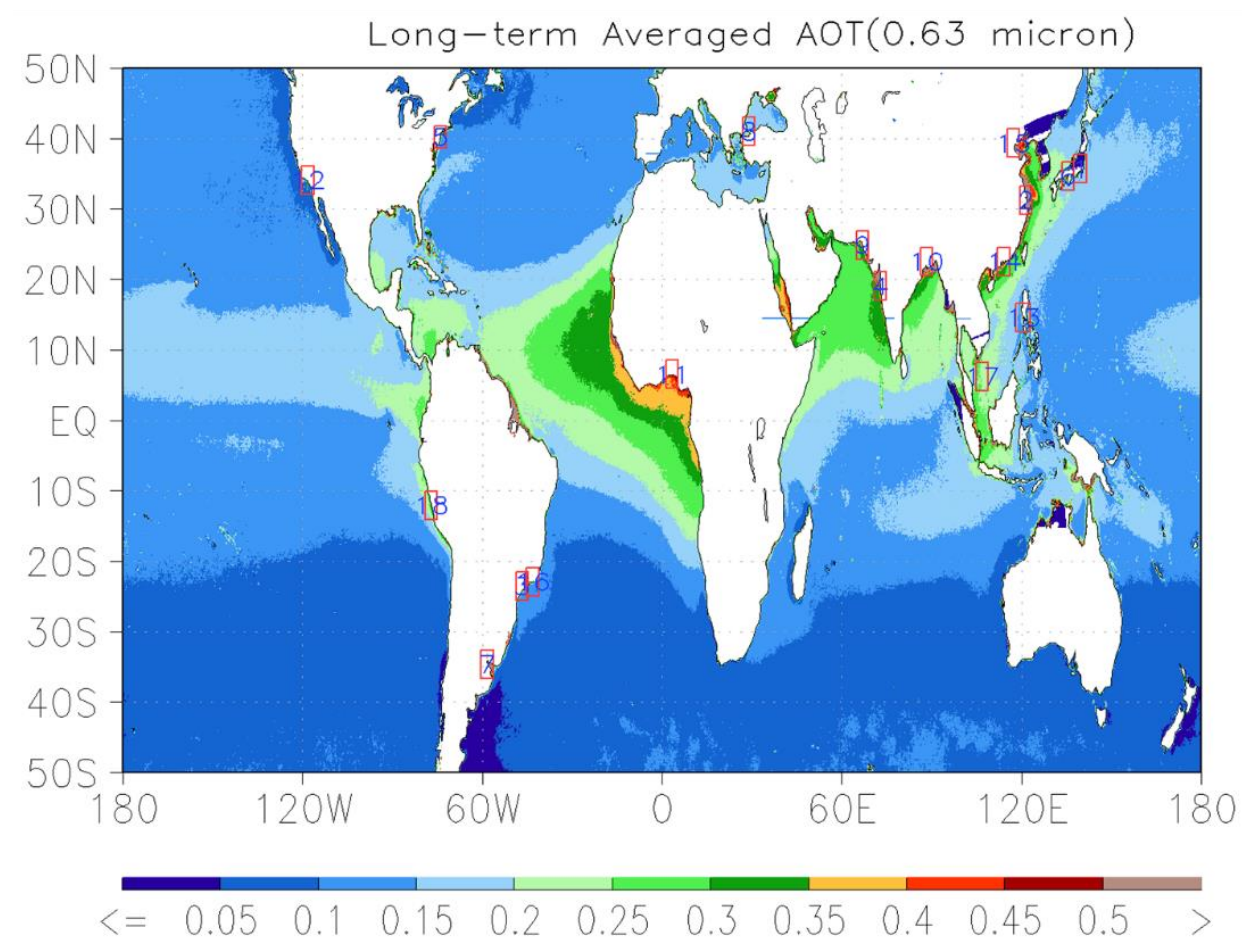

Figure 2. Temporally averaged (1982-2019) monthly mean AVHRR AOT on 0.63- $\mu$ m wavelength over the global oceans along with the locations of $18 \mathrm{MCCZ}$ marked by the red square boxes.

\subsubsection{Satellite Data}

Version 3 of NOAA operational satellite AVHRR AOT CDR (http:/ / doi.org/10.7289/ V5BZ642P, accessed on 3 November 2021) is used in this study. The AVHRR AOT CDR is derived over global water (or ocean) surface at $0.63-\mu \mathrm{m}$ wavelength channel using a two-channel AVHRR aerosol retrieval algorithm [35] from the AVHRR clear-sky reflectance, which is determined from the NOAA Pathfinder Atmospheres-Extended (PATMOS-x) AVHRR all-sky reflectance and cloud probability CDR products [36]. Due to the limited channels of AVHRR instrument, only aerosol retrieval over water can be obtained and of that, only the AOT retrieved from $0.63-\mu \mathrm{m}$ channel achieves a climate quality, because the retrieval from the wider $0.86-\mu \mathrm{m}$ channel is contaminated by water vapor absorption, which is difficult to be accurately quantified, especially for AOT trend detection. The retrieval algorithm has been validated by comparing it with the Aerosol Robotic Network (AERONET) ground AOT measurement $[35,37]$ and the Moderate Resolution Imaging Spectroradiometer (MODIS) satellite AOT observation [38]. In this study, the global monthly AVHRR AOT $(0.63-\mu \mathrm{m})$ CDR product from 1982 to 2020 in $0.1^{\circ} \times 0.1^{\circ}$ equal angle grid is used. Figure 3 shows the AOT linear trend from 1982 to 2019 and its significance over the global ocean derived from the long-term AVHRR AOT CDR. A positive AOT trend with a confidence level above 95\% (or the significance value $>2$ in Figure $3 b$ ) is observed over the east coastal oceans of China, the Arabian Sea, the Bay of Bengal, the west coastal ocean of South Africa, and the Mozambique Channel. At the same time, a distinct negative AOT trend with a confidence level above $95 \%$ (or the significance value $<-2$ in Figure $3 b$ ) is observed over the east coastal ocean of the United States, the west coastal ocean of Europe, and the Mediterranean Sea. 


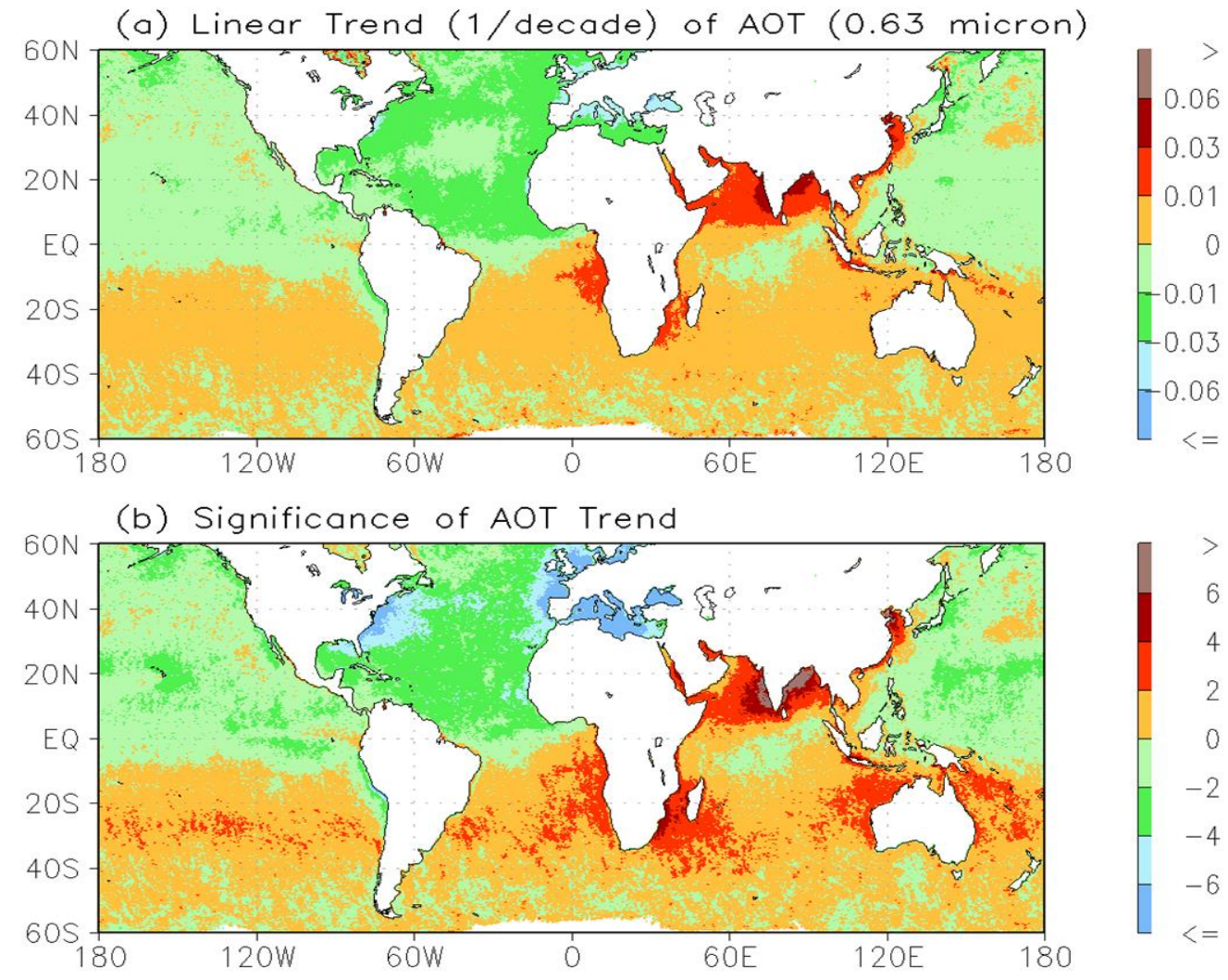

Figure 3. (a) Linear long-term trend (1/decade) of AOT on $0.63-\mu \mathrm{m}$ wavelength over the global oceans along with (b) the corresponding significance of the trend. The warm color indicates positive trend while the cold color indicates negative trend. For the significance $>| \pm 2|$, the detected trend is above $95 \%$ confidence level.

\subsubsection{Reanalysis Data}

In our analysis, we also use the monthly reanalysis data of seven meteorological variables: planetary boundary layer height (PBLH); precipitable water in atmospheric column (PW); relative humidity at 2-m (RH); surface temperature at 2-m (TMP); U, V components of surface wind speed at $10-\mathrm{m}$ and $850-\mathrm{mb}$; and pressure vertical velocity at 0.995 sigma level $(\omega)$. These variables are used to examine the possible effect of meteorological conditions on AOT. PBLH may limit the vertical dispersion and ventilation of surface pollution emissions, PW may influence the washout of aerosol particles, RH and TMP are important for the hygroscopic growth of aerosol particles, $\mathrm{U}, \mathrm{V}$, and $\omega$ are important for horizontal and vertical transport of aerosol particles. The monthly reanalysis data with a latitude and longitude resolution of $0.5^{\circ} \times 0.5^{\circ}$ is obtained from National Centers for Environmental Prediction (NCEP) climate forecast system reanalysis (CFSR) [39] monthly mean product (ftp:/ / nomads.ncdc.noaa.gov/CFSR/HP_monthly_means/, accessed on 13 May 2020). The selected meteorological variables from CFSR monthly mean products from 1982 to 2020 are further interpolated into the same spatial resolution $\left(0.1^{\circ} \times 0.1^{\circ}\right)$ as the satellite AOT CDR product used in this study.

\subsection{Methods}

\subsubsection{Analyzing AOT Differences}

Offshore airflows may travel hundreds to thousands of kilometers from the emission source regions over land to downwind oceanic areas, where AOT changes are not necessarily linearly correlated with the emission changes in the source regions. This is due to the complex chemical and microphysical changes of aerosol particles during the transport, along with the effect of meteorological conditions. Thus, two types of annual AOT difference are computed in this study for the $18 \mathrm{MCCZ}$ to assess the impact of lockdowns on 
the aerosol loading in their surrounding coastal oceanic areas. The first type is the annual AOT difference between 2020 with the influence of COVID-19 lockdown and 2019 without the lockdown influence (named as Type-1 AOT difference hereafter). The second type of AOT difference (or Type-2 AOT difference) is the AOT annual anomaly for 2020 with the influence of COVID-19 lockdown relative to the corresponding annual climatology of AOT (without the influence of lockdown). Thirty-eight years (1982-2019) of annual mean AOT were used to compute the AOT annual climatology for a square box of $\pm 2^{\circ}$ latitude and longitude around each of the $18 \mathrm{MCCZ}$. For example, the AOT annual climatology for a MCCZ is the arithmetical mean of 38 annual mean AOT values from 1982 to 2019 for the defined box around the MCCZ. Consistent changing tendency obtained from these two types of annual AOT differences for 2020 should be more useful in assessing the impact of COVID-19 lockdowns than the result based solely on either one of them.

\subsubsection{Linear Regression of Multiple Variables}

Meteorological conditions may enhance or weaken the AOT changes due to the COVID-19 lockdown. Therefore, it is worthwhile to examine the correlation of AOT with the meteorological variables that have a potential influence on AOT for the $18 \mathrm{MCCZ}$. Since we have a long-term AOT CDR, we performed a linear regression of multiple meteorological variables with AOT $(\tau)$ for the defined box of selected MCCZ, as expressed in Equation (1):

$$
\tau_{i}^{j}=a_{0}^{j}+a_{1}^{j} x_{1, i}^{j}+a_{2}^{j} x_{2, i}^{j}+\cdots+a_{7}^{j} x_{7, i}^{j}
$$

where $j(=1,2,3, \ldots, 18)$ is one of the $18 \mathrm{MCCZ}$ and $i$ is the index of year, which changes from 1 (1982) to 38 (2019). $x_{1}, x_{2}, \ldots, x_{7}$ are seven meteorological variables (PBLH, PW, $\mathrm{RH}, \mathrm{TMP}, \mathrm{U}, \mathrm{V}$, and $\omega$ ) selected from the CFSR reanalysis. $a_{0}$ is the constant term and $a_{1}, a_{2}$, $\ldots, a_{7}$ are seven linear regression parameters (or slopes).

\section{Results}

\subsection{Annual AOT Changes}

Consistent changing tendency obtained from the analysis of Type- 1 and Type- 2 annual AOT differences for 2020 should be more useful in assessing the impact of COVID-19 lockdowns than the result based solely on either one of them. Figure 4 shows the two types of annual AOT differences in a relative percentage for the $18 \mathrm{MCCZ}$. The detrended annual AOT anomaly for 2020 is also shown in Figure 4 (discussed in the next subsection). Consistent negative values for the two types of annual AOT differences are observed for 13 MCCZ. Negative AOT changes are anticipated as the lockdown consequence because anthropogenic pollution emissions are reduced due to reduced human activities during the lockdown period. Unexpectedly, Los Angeles has consistent positive values for the two types of annual AOT differences while four MCCZ (Osaka Kobe, Lagos, Tianjin, and Lima) show positive for Type-1 AOT difference, but negative for Type-2 AOT difference. These unexpected AOT changes in a few MCCZ during the pandemic year may be due to other AOT variations, such as interannual variations (including long-term trends), that may conceal the AOT change due to the lockdown, making it indiscernible in satellite observations over the coastal oceans around the MCCZ. More analyses are performed to explore the causes of the unexpected AOT changes in the pandemic year and the results are given below. 


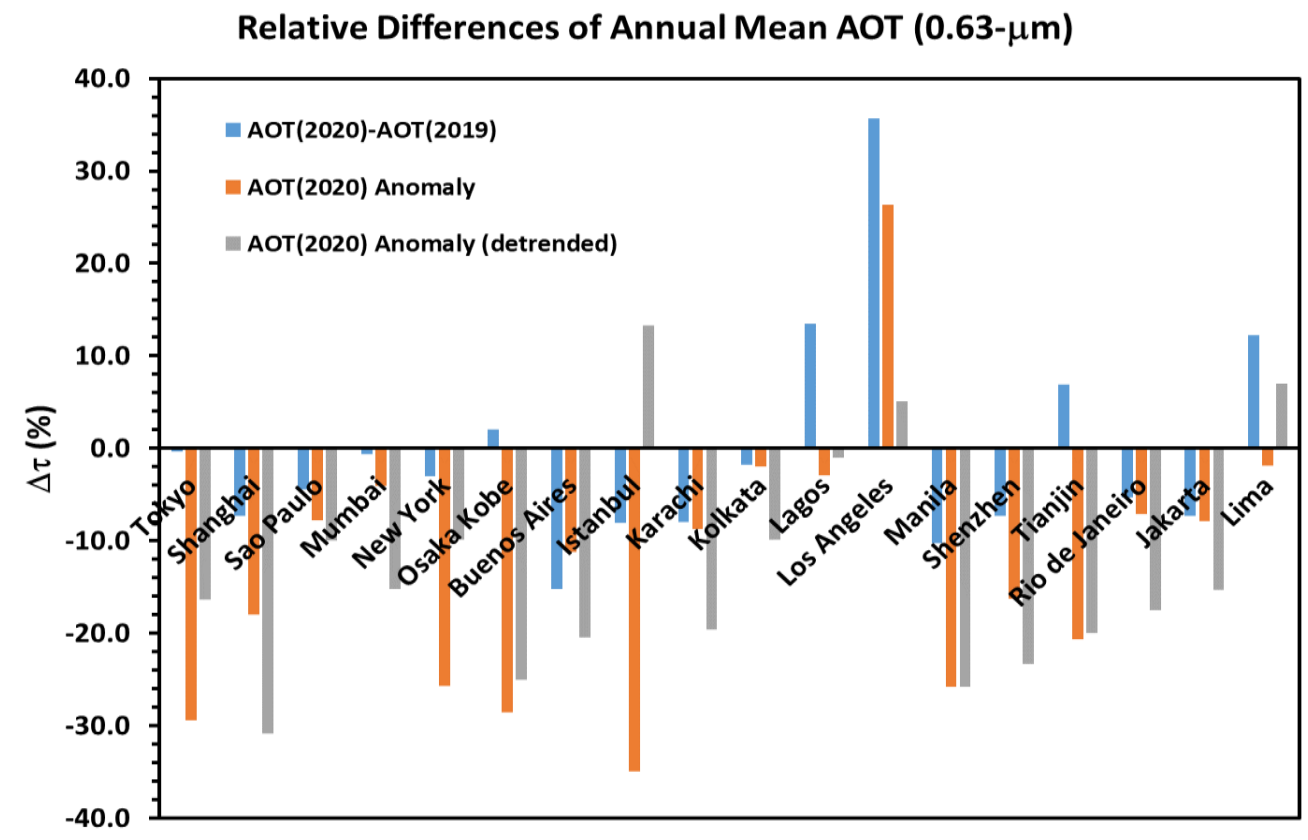

Figure 4. Annual AOT (or $\tau$ ) difference $(\Delta \tau)$ in percentage (\%) between 2020 with the COVID-19 lockdown and 2019 without the lockdown, 2020 annual AOT anomaly, and detrended 2020 annual AOT anomaly.

\subsection{Long-Term Trend Effect}

Significant long-term AOT linear trends over some coastal oceans (Figure 3) may conceal AOT changes caused by the COVID-19 lockdown. Figure 4 also shows the detrended annual mean AOT anomaly of 2020 for the $18 \mathrm{MCCZ}$. Of the $13 \mathrm{MCCZ}$ with consistent negative values in the two types of annual AOT difference in 2020, 12 had annual AOT anomalies stay negative, and the values are between $-1 \%$ and $-30 \%$ after the trend effect is removed, suggesting that the trend effect is not the major cause for the AOT changes in 2020 with COVID-19 lockdown for these $12 \mathrm{MCCZ}$. Istanbul is the only city among the 13 MCCZ that changes the negative 2020 annual AOT anomaly to positive after the trend effect is removed. This suggests the distinct negative long-term trend over the coastal ocean surrounding Istanbul (see Figure 3) is the major cause of its negative 2020 annual AOT anomaly rather than the lockdown effect. However, the lockdown effect on Istanbul's AOT in 2020 is still noticeable (-8\%) when it is compared to 2019's AOT, since the difference of the trend effect is not as distinctive as the lockdown effect between these two consecutive years.

Lima is one of the four MCCZ (Osaka Kobe, Lagos, Tianjin, and Lima) with positive Type- 1 but negative Type-2 AOT difference in 2020 (see Figure 4). After the long-term trend is removed, the 2020 annual AOT anomaly changes from negative (-2\%) to positive $(7 \%)$ in Lima. This suggests that the evident negative AOT trend over Lima coastal ocean (see Figure 3) is probably responsible for the negative 2020 annual AOT anomaly. After the long-term trend effect is removed, unexpected consistent positive values for the two types of annual AOT difference appear. Figure 5 shows the detrended seasonal AOT anomaly for Lima. The major positive 2020 AOT anomaly comes from December-January-February (DJF), when the coronavirus had not yet spreaded to South America. The seasonal AOT anomaly becomes negative when the coronavirus lockdown was implemented in the later three seasons (Table 1). The positive AOT anomaly in DJF overwhelms the combined negative AOT anomaly of the other three seasons with the lockdown effect. Daily surface PM2.5 measurement also indicates that DJF is the most polluted season in Lima and there is an evident decrease in the amount of PM2.5 after the lockdown was implemented in March 2020 [6]. 


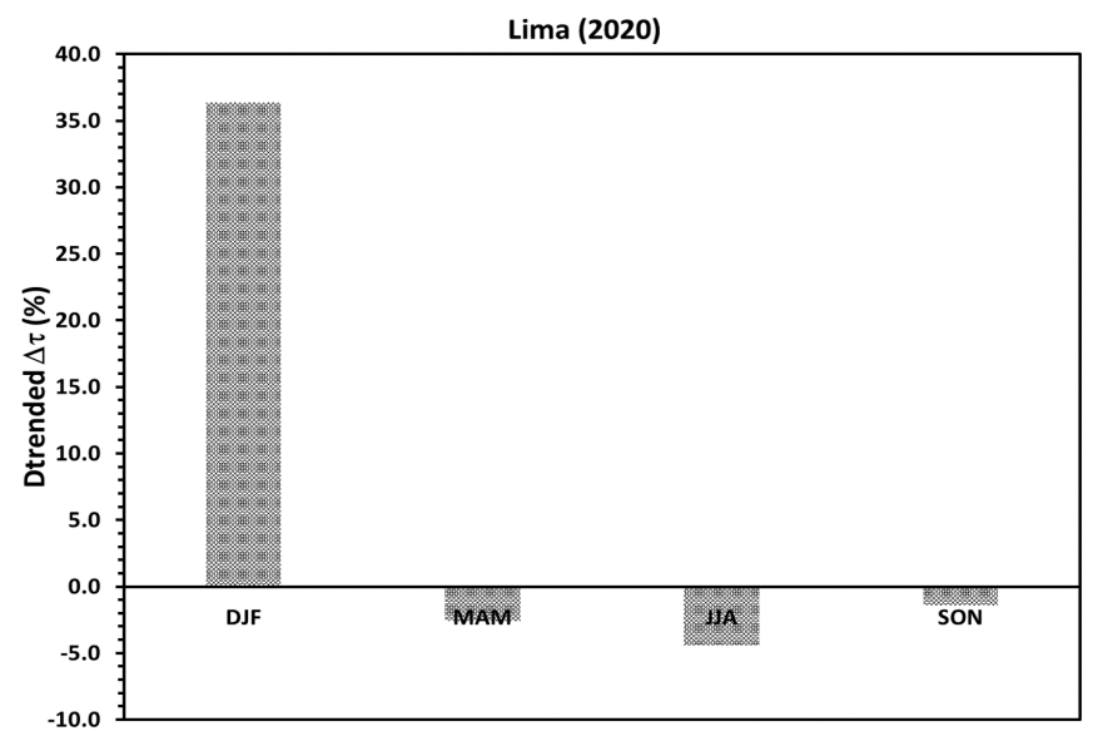

Figure 5. Detrended AOT anomaly for the four seasons December-January-February (DJF), MarchApril-May (MAM), June-July-August (JJA), September-October-November (SON) of 2020 in Lima. DJF is the season without lockdown since the coronavirus had not yet spread to Lima.

For Osaka Kobe, Lagos, and Tianjin, Type-2 AOT difference stays negative after the long-term trend effect is removed, which suggests the trend effect may be not as important as the lockdown effect. However, their Type-1 AOT differences are positive rather than negative, as expected for the lockdown effect. This suggests other AOT interannual variations aside from the long-term trend may play a more important role for the AOT changes in 2020 relative to 2019. Los Angeles' positive Type-2 AOT difference stays positive after the long-term trend effect is removed, but its Type-1 AOT difference is also positive. Other interannual variations aside from the long-term trend and lockdown effect may be responsible for the consistent positive values of the two types of annual AOT difference in Los Angeles. Thus, further analyses and discussions on other AOT interannual variations are given below to provide more insight as to the causes of AOT changes in 2020 in addition to the effects of COVID-19 lockdown and the AOT long-term trend.

\section{Discussion}

As we mentioned above, the meteorological conditions may enhance or weaken the AOT changes due to the COVID-19 lockdown. Therefore, using Equation (1), we examined the correlation of AOT with the meteorological variables that have a potential influence on AOT for the $18 \mathrm{MCCZ}$. Table 2 lists the individual linear correlation coefficients $\left(C_{i}, i=1,2, \ldots, 7\right)$ for the seven meteorological variables and the ensemble multiple linear correlation coefficient $(C)$, which are normalized to 100 and expressed in the unit of percentage (\%), obtained from the multiple variable linear regression of Equation (1) for the $18 \mathrm{MCCZ}$. Even though the influence of individual seven meteorological variables on AOT is generally below $50 \%$, their multiple ensemble influence may be above $50 \%$. Meteorological conditions show the largest influence on AOT in Istanbul $(C=79.75 \%)$. This suggests that the positive annual AOT anomaly in 2020 noted for Istanbul in Figure 4 after the long-term trend effect is removed is probably due to the AOT change caused by the interannual variation of meteorological conditions. The lowest influence of meteorological conditions on AOT is in Los Angeles $(C=16.31 \%)$ but the consistent positive values of two types of annual AOT difference noted for Los Angeles in Figure 4 are unexpected for the lockdown effect, which will be discussed further below. The influence of meteorological conditions on AOT is also very low in Manila $(C=21.25 \%)$, so the consistent negative values of two types of AOT difference ( - $26 \%$ ) noted for Manila in Figure 4 should be mainly due to reduced pollution emissions during the COVID-19 lockdown. Praveena and Aris [40] indicated that the PM2.5 amount was reduced by about $25 \%$ on average after 
the lockdown was enforced in Manila (monitored by the air pollution index of Malaysia; http:/ /apims.doe.gov.my/public_v2/home.html, accssed on 3 November 2021).

Table 2. The correlation coefficients from the multiple variable linear regression of Equation (1) for the $18 \mathrm{MCCZ}$. The correlation coefficients are normalized to 100 and expressed in the unit of percentage (\%). The highest negative or positive correlation coefficient among the seven individual correlation coefficients for the seven meteorological variables (PBLH, PW, $\mathrm{RH}, \mathrm{TMP}, \mathrm{U}, \mathrm{V}$, and $\omega$ ) is highlighted in bold font for each MCCZ. The multiple linear correlation coefficient represents the ensemble correlation of AOT with the seven meteorological variables.

\begin{tabular}{|c|c|c|c|c|c|c|c|c|c|}
\hline \multirow[b]{2}{*}{ No } & \multirow[b]{2}{*}{ Megacity } & \multicolumn{7}{|c|}{ Individual Linear Correlation Coefficients (\%) } & \multirow{2}{*}{$\begin{array}{l}\text { Multiple Linear } \\
\text { Correlation } \\
\text { Coefficient }(\%)\end{array}$} \\
\hline & & $\begin{array}{c}\mathrm{C}_{1} \\
(\mathrm{PBLH})\end{array}$ & $\mathrm{C}_{2}(\mathrm{PW})$ & $\mathrm{C}_{3}(\mathrm{RH})$ & $\mathrm{C}_{4}(\mathrm{TMP})$ & $\mathrm{C}_{5}(\mathrm{U})$ & $\mathrm{C}_{6}(\mathrm{~V})$ & C7 $(\omega)$ & \\
\hline 1 & Tokyo & -36.27 & -12.27 & -26.12 & -39.17 & -19.92 & -3.84 & -49.81 & 70.29 \\
\hline 2 & Shanghai & 13.48 & 26.21 & 8.51 & 33.20 & 4.32 & -3.77 & 13.55 & 51.49 \\
\hline 3 & Sao Paulo & 0.07 & 10.27 & 18.11 & 22.50 & 25.63 & 24.19 & 13.56 & 61.57 \\
\hline 4 & Mumbai & -0.64 & 38.90 & 34.66 & 34.05 & -20.87 & -8.89 & -35.18 & 53.69 \\
\hline 5 & New York & 25.46 & -34.06 & -43.90 & -15.15 & 18.43 & -0.02 & 43.18 & 60.71 \\
\hline 6 & $\begin{array}{l}\text { Osaka } \\
\text { Kobe }\end{array}$ & -36.58 & -3.60 & -28.77 & -14.51 & -20.10 & -16.75 & 40.96 & 59.40 \\
\hline 7 & $\begin{array}{c}\text { Buenos } \\
\text { Aires }\end{array}$ & 7.01 & -23.94 & -16.24 & -21.14 & 11.61 & -22.12 & 20.80 & 33.85 \\
\hline 8 & Istanbul & -21.61 & -45.56 & -35.35 & -17.62 & -2.43 & -53.65 & -35.79 & 79.75 \\
\hline 9 & Karachi & -16.89 & 44.20 & 36.13 & 41.13 & -25.48 & -13.95 & -13.83 & 60.67 \\
\hline 10 & Kolkata & 12.61 & 27.73 & 28.05 & 15.78 & 4.10 & -17.37 & -4.25 & 60.72 \\
\hline 11 & Lagos & 33.00 & -1.47 & -2.70 & -24.35 & -11.18 & -9.71 & -6.47 & 53.92 \\
\hline 12 & $\begin{array}{c}\text { Los } \\
\text { Angeles }\end{array}$ & -6.04 & -7.96 & -7.41 & -5.53 & -8.66 & -2.33 & -7.76 & 16.31 \\
\hline 13 & Manila & 1.40 & -11.65 & -12.00 & -5.43 & 5.32 & -3.98 & -2.28 & 21.25 \\
\hline 14 & Shenzhen & -3.11 & 13.74 & 9.40 & 4.29 & 15.52 & -4.07 & -20.19 & 39.88 \\
\hline 15 & Tianjin & 0.96 & 20.47 & -36.14 & 17.21 & -20.95 & 4.14 & -26.40 & 64.88 \\
\hline 16 & $\begin{array}{l}\text { Rio de } \\
\text { Janeiro }\end{array}$ & 8.42 & 3.09 & 11.99 & 16.75 & 12.81 & 13.93 & 30.39 & 62.02 \\
\hline 17 & Jakarta & 16.46 & -15.11 & -17.42 & 15.84 & -32.56 & -12.00 & 16.33 & 44.19 \\
\hline 18 & Lima & 32.77 & -15.75 & -21.60 & 3.78 & -26.77 & -32.28 & -45.41 & 58.14 \\
\hline
\end{tabular}

In addition to Istanbul, Tianjin, Osaka-Kobe, and Lagos are the three MCCZ that show the opposite sign for Type- 1 AOT difference and the detrended Type-2 AOT difference in 2020 (see Figure 4). However, their Type-1 AOT difference in 2020 is positive and the detrended Type-2 AOT difference is negative, which is opposite to that of Istanbul. Type-1 AOT difference for 2020 in Tianjin is positive rather than negative as are the other two MCCZ in China (Shanghai and Shenzhen). Dust storms are the major source of PM in northern and northeastern China during winter and spring [41-43], which is when the COVID-19 outbreak developed into an epidemic. The lockdown measures implemented in China to contain the spread of the coronavirus mainly affect anthropogenic emissions rather than natural mineral dust particles blowing up from the land surface. The dust storm events in 2020 were probably more active in 2020 than in 2019, so the corresponding increase of AOT mineral dust component surpasses the reduction of AOT anthropogenic component due to the emission reduction related to the lockdown in the northeastern megacity Tianjin. Because the influence of dust events is relatively weak in the southern and southeastern coasts of China, the AOT difference between 2020 and 2019 observed 
in Shenzhen and Shanghai is mainly due to the lockdown effect. Figure 6 shows AOT distribution over the east coastal oceans of China for 2020 and 2019 (Figure 6a,b) and their difference as a relative percentage (Figure $6 c, d$ ) overlaid with wind vectors at $10-\mathrm{m}$ altitude and $850-\mathrm{mb}$ pressure level, respectively. In 2019, the westerly and northwesterly winds near the surface $(10-\mathrm{m})$ and close to the top of the planetary boundary layer $(850-\mathrm{mb})$ over northern China blow more aerosols (including dust particles) that originated from the continent offshore to the downwind Bohai Sea (see Figure $6 c, d$ ). Thus, annual mean AOT over the Bohai Sea is higher in 2020 than in 2019, which results in the positive AOT difference between 2020 and 2019 observed in Figure 4 for Tianjin. Because the strong westerly winds can blow aerosols (including dust particles) that originated from the China continent to Korea and Japan $[42,44,45]$, the behavior of the two types of annual AOT difference in Osaka-Kobe are similar to those of Tianjin.

(a)AOT; Wind $(\mathrm{m} / \mathrm{s})$ on $10 \mathrm{~m} ; 2019$

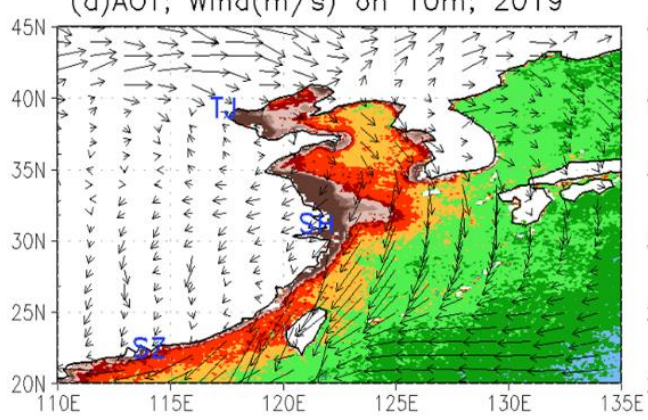

(b)AOT; Wind $(\mathrm{m} / \mathrm{s})$ on $10 \mathrm{~m} ; 2020$

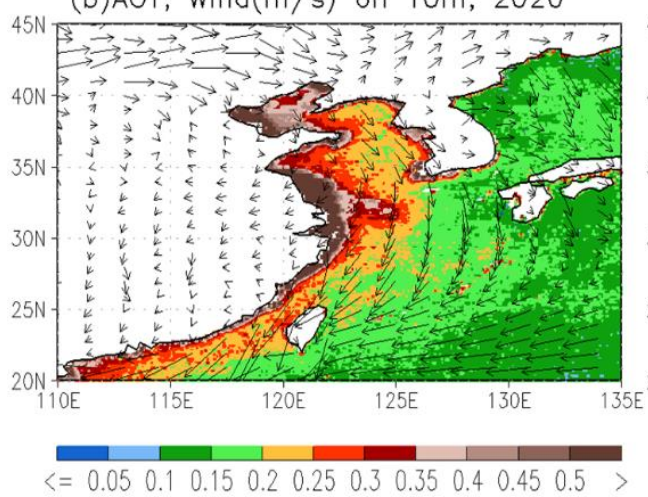

(c) dAOT(\%); Wind $(\mathrm{m} / \mathrm{s})$ on $850 \mathrm{mb} ; 2019$

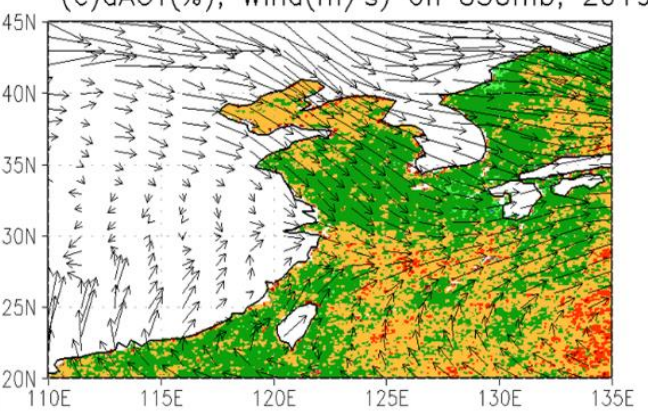

(d) dAOT $(\%) ; \operatorname{Wind}(\mathrm{m} / \mathrm{s})$ on $850 \mathrm{mb} ; 2020$

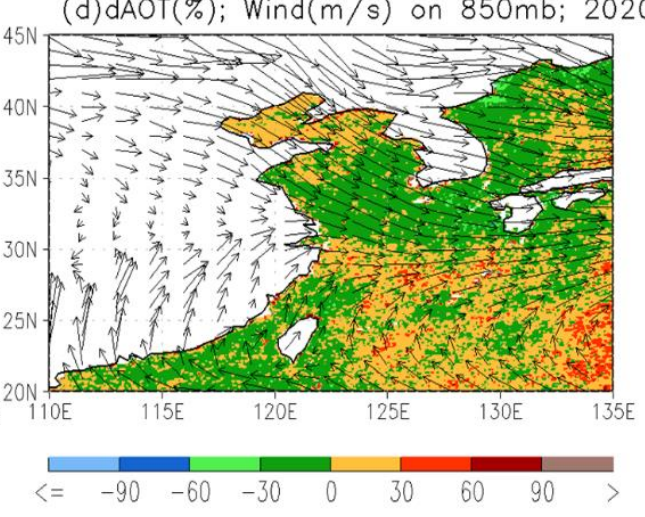

$\overrightarrow{3.0}$

Figure 6. AOT distributions over the east coastal oceans of China for (a) 2019 and (b) 2020 along with their difference in a relative percentage $(\%)$ in $(\mathbf{c}, \mathbf{d})$, which are overlaid with the wind vectors at $10-\mathrm{m}$ altitude and 850-mb pressure level, respectively. Tianjin (TJ), Shanghai (SH), and Shenzhen (SZ) are marked in plot (a) with letters in blue.

In Lagos, biomass burning aerosol from Sahel and west-central Africa is a major aerosol component in addition to the anthropogenic aerosol component, especially in summer and fall, which are the peak burning seasons. Similar to Tianjin, natural biomass burning events in Lagos were probably more active in 2020 than in 2019 since the air was drier $(\Delta \mathrm{RH}<0)$ and less precipitation was available $(\Delta \mathrm{PW}<0)$ in 2020 compared to 2019 (Figure 7). Figure 8 also shows that the positive detrended Type-2 seasonal AOT difference in 2020 comes from JJA and SON, which are the biomass burning seasons. Thus, the corresponding increase of AOT biomass burning component may surpass the reduction of AOT anthropogenic component due to the emission reduction related to the lockdown in 2020, which interprets the AOT annual difference between 2020 and 2019 as positive rather than negative in Lagos. 
(a) IPWAT(\%); 2020-2019

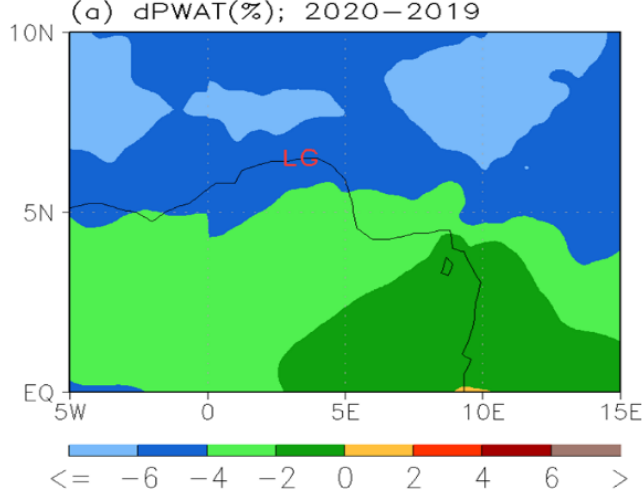

(b) $\mathrm{dRH}(\%) ; 2020-2019$

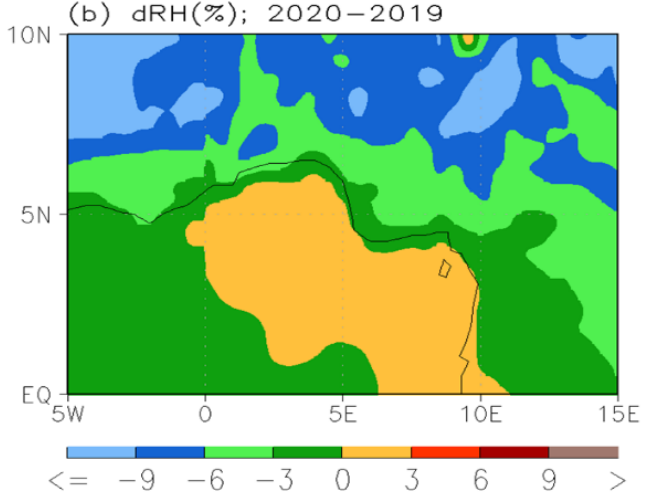

Figure 7. Distribution for the difference in percentage (\%) of (a) column precipitable water (PW) and (b) relative humidity (RH) at 2-m altitude between 2020 and 2019 in the surrounding areas of Lagos. The city of Lagos is marked in plot (a) with letters LG in red color.

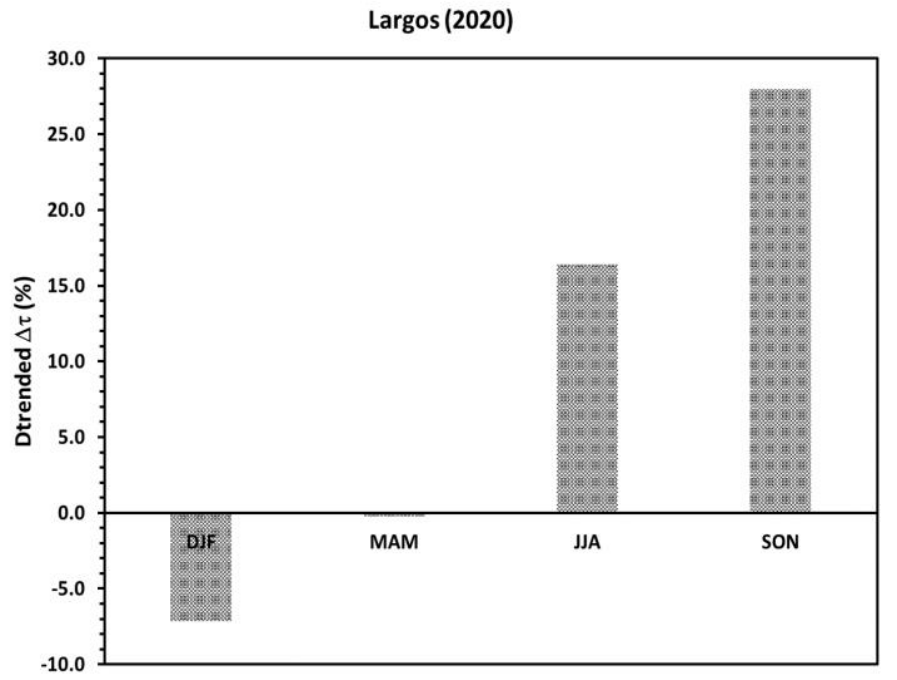

Figure 8. Detrended seasonal AOT anomaly of 2020 in Lagos. JJA and SON are the biomass burning seasons.

For Los Angeles, the two types of annual AOT difference are positive in 2020 and the AOT annual anomaly remains positive after the AOT long-term trend effect is removed (see Figure 4). This implies there may be other AOT interannual variation masking the effect of loosely implemented lockdown measures in Los Angeles. Figure 9 compares monthly AOTs and the detrended AOT anomaly between 2019 and 2020, respectively. It suggests the positive two types of annual AOT difference of 2020 are mainly due to the contribution of higher AOT values in the summer and fall of 2020. The air was generally drier $(\Delta \mathrm{RH}<0)$ and less precipitation was available $(\Delta \mathrm{PW}<0)$ in 2020 compared to 2019 in the vicinity of Los Angeles over land area as well as over all of California (Figure 10). According to news reports, more severe forest and bush fires occurred in the summer and fall of 2020 in California. Figure 11 shows the map of Type-1 seasonal AOT difference as a relative percentage over the coastal ocean of Los Angeles for fall 2020, overlaid with seasonal wind vectors on $10-\mathrm{m}$ altitude and $850-\mathrm{mb}$ pressure level, respectively. The strong winds blow from northwest to southeast along the coastal lines over both ocean and land, which transports the enhanced AOT due to the fire smoke from the northern upwind coastal ocean to the downwind coastal ocean around the city. 

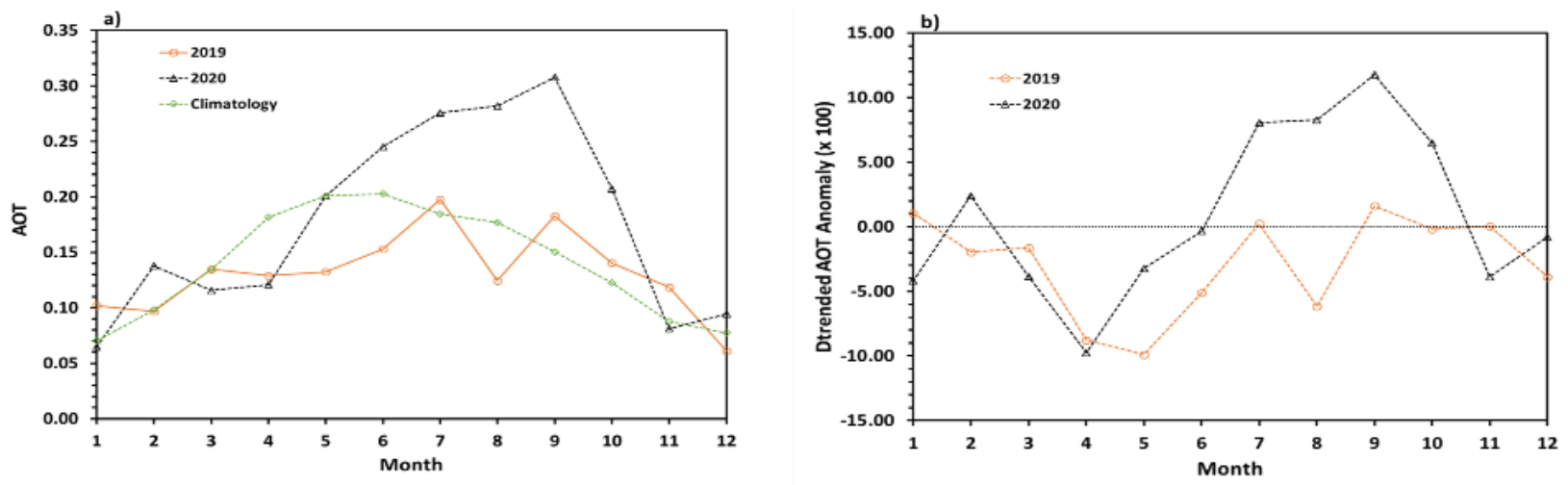

Figure 9. (a) Monthly AOT plot of 2019, 2020, and the climatology along with (b) the plot of detrended monthly AOT anomaly of 2019 and 2020 in Los Angeles.

(a) dPWAT(\%); 2020-2019

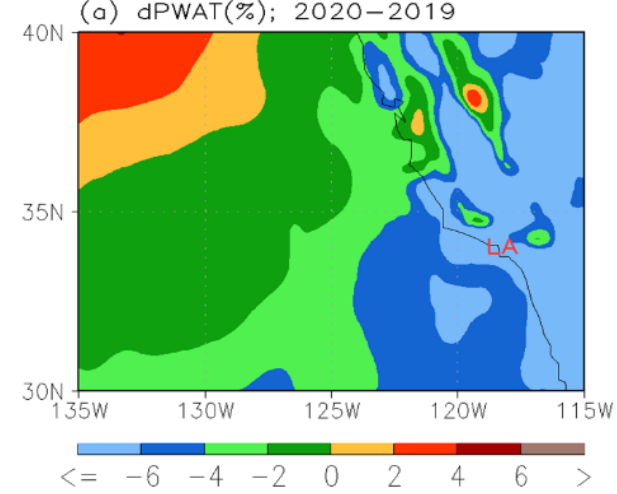

(b) $\mathrm{dRH}(\%) ; 2020-2019$

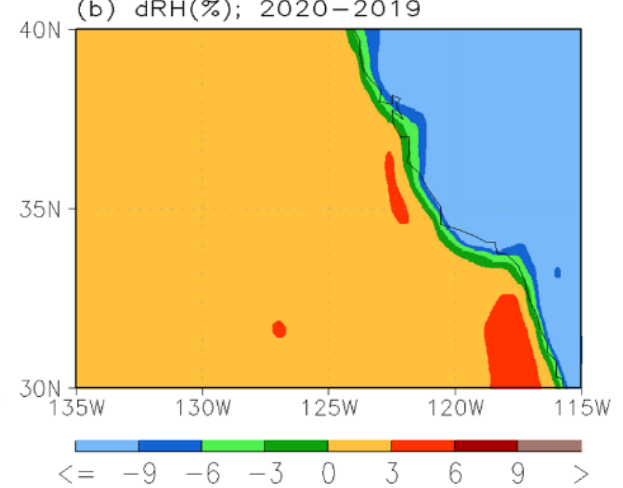

Figure 10. Distribution for the difference (\%) of (a) column precipitable water (PW) and (b) relative humidity (RH) at 2-m altitude between 2020 and 2019 in the surrounding areas of Los Angeles. The city of Los Angeles is marked in plot (a) with letters LA in red.

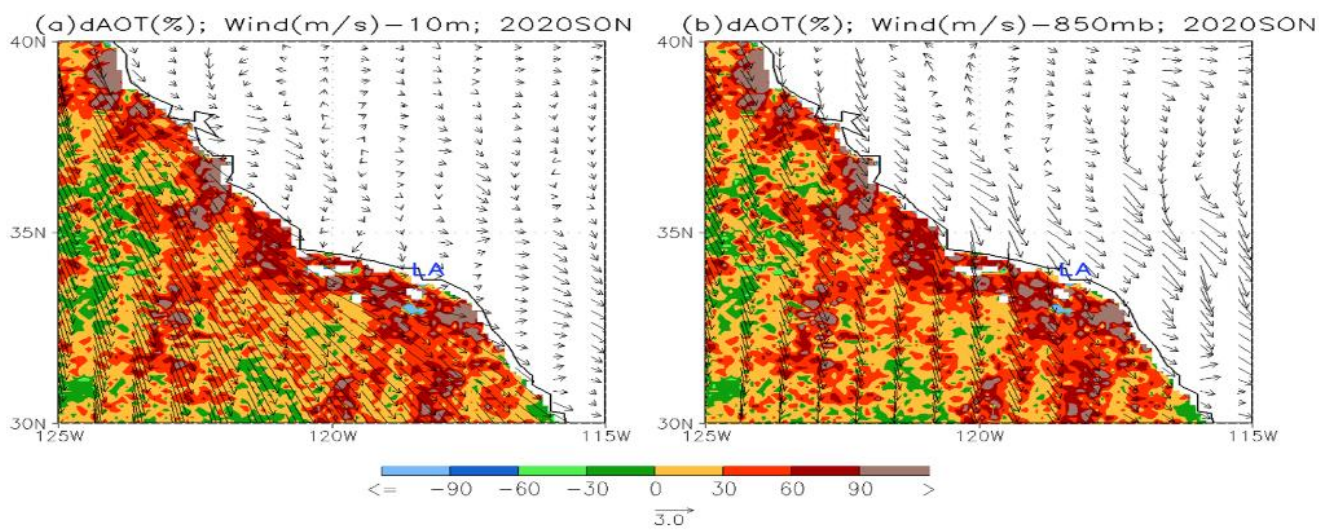

Figure 11. Distributions of AOT difference (\%) between 2020 and 2019 in bush and forest fire-burning season SON over the coastal ocean of California, which is overlaid with the wind vectors at (a) 10-m altitude and (b) 850-mb pressure level, respectively. The city of Los Angeles is marked in plot with letters LA in blue.

The above analyses on unexpected AOT changes for the special cases of Tianjin, Osaka-Kobe, Lagos, and Los Angeles indicate our previous assumption that most of the aerosols are near ground or in PBL of an urban environment is not valid anymore for these four MCCZ. Moreover, the changes of emission scenarios during the lockdown period are also much more complex, for example, pollution emissions from heavy-duty vehicles may be reduced but private cars' emissions may be increased during the lockdown 
period as observed by Dantas et al. [9], especially in the MCCZ with only partial lockdown implemented. As a result, AOT changes are much more complex for these special cases so that AOT changes are not linearly correlated with the emission changes in source regions or do not even necessarily represent the local emission changes associated with the lockdown. We also focused our analysis on the domain averaged AOT annual mean values and annual mean anomaly instead of individual instantaneous or daily mean AOT values in order to minimize the bias caused by potential data gaps due to the limitations of passive AVHRR aerosol observation (such as aerosol retrieval is only available in clear sky condition). As a result, our analysis based on the two types of annual AOT difference may miss some detailed AOT changes due to the lockdown for these special cases. Therefore, further investigation on more detailed characteristics of AOT changes and the mechanisms in aerosol chemical and transport processes for these special cases during the COVID-19 lockdown are needed in a future study by combing observations in high spatial and temporal resolution over both land source region and downwind coastal oceanic areas with chemical and transport model simulations.

\section{Conclusions}

Nearly 40 years of AOT CDR derived from NOAA AVHRR operational satellites observation over the global oceans is used to study the AOT changes due to the COVID-19 lockdown over the surrounding coastal oceanic areas of 18 megacities in the coast zone. Both AOT difference between annual AOT values of 2020 with COVID-19 lockdown and 2019 without the lockdown and 2020 AOT annual anomaly are used to better-identify the AOT changes due to the lockdown. Consistent changing tendencies of AOT in these two types of AOT difference can help us effectively discern and confirm the AOT change due to the lockdown from other factors.

For most of the 18 MCCZ studied, the COVID-19 lockdowns implemented to contain the spread of coronavirus resulted in decreased AOT with a magnitude between $-1 \%$ and $-30 \%$ due to the reduction of anthropogenic emissions associated with the lockdown. For some MCCZs, such as Istanbul and Lima, the distinct negative AOT long-term trend may replace the lockdown effect and become the dominant contributor to the negative annual AOT anomaly. At the same time, for a few MCCZ, other interannual variations of aerosol amount due to favorable or unfavorable meteorological conditions may also mask the AOT changes due to the lockdown effect. For example, the interannual variation of the dust aerosol component over northern and northeastern China and its long-range transport may mask the AOT reduction due to the lockdown effect in 2020 relative to 2019 without the lockdown effect. Different seasonal variations of aerosol amount in 2020 relative to 2019 due to other emission sources, such as biomass burning for Lagos, bush and forest fires and smoke for Los Angeles, along with meteorological conditions may conceal the limited AOT reduction in annual AOT value due to loosely implemented lockdown measures in 2020.

This study indicates that the long-term satellite observation is useful for studying and monitoring the aerosol changes due to the emission reduction associated with COVID-19 lockdowns in MCCZ and their surrounding coastal areas, which will benefit the future development of mitigation strategies for air pollution and emissions in megacities.

Author Contributions: In this article; Conceptualization, X.Z.; methodology, K.W. and X.Z.; formal analysis, K.W. and X.Z.; investigation, K.W. and X.Z.; data curation, K.W. and X.Z.; writing-original draft preparation, K.W. and X.Z.; writing-review and editing, K.W. and X.Z..; supervision, X.Z.; project administration, X.Z.; funding acquisition, X.Z. All authors have read and agreed to the published version of the manuscript.

Funding: This research was funded by the base funding of the National Centers for Environmental Information (NCEI) at NOAA/NESDIS.

Data Availability Statement: The data sources used in this study have been provided in Section 2 with the data weblinks. For the data produced in this study, please email to the corresponding author. 
Acknowledgments: We would like to thank for the comments and suggestions from two anonymous NCEI internal reviewers. We also would like to acknowledge the constructive comments from three anonymous reviewers, which are very helpful for improving our paper. Proofreading of the paper by English editor Andrea Andersen of NCEI is also greatly appreciated. The views, opinions, and findings contained in this paper are those of the authors and should not be construed as an official National Oceanic and Atmospheric Administration or U.S. Government position, policy, or decision.

Conflicts of Interest: The authors declare no conflict of interest.

\section{Acronyms}

$\begin{array}{ll}\text { AERONET } & \text { Aerosol Robotic Network } \\ \text { AOT } & \text { aerosol optical thickness } \\ \text { AVHRR } & \text { Advanced Very High Resolution Radiometer } \\ \text { CCN } & \text { cloud condensation nuclei } \\ \text { CDR(s) } & \text { climate data record(s) } \\ \text { CFSR } & \text { climate forecast system reanalysis } \\ \text { COVID-19 } & \text { coronavirus disease 2019 } \\ \text { DJF } & \text { December-January-February } \\ \text { JJA } & \text { June-July-August } \\ \text { NASA } & \text { National Aeronautics and Space Administration } \\ \text { MAM } & \text { March-April-May } \\ \text { MCCZ } & \text { Mega Cities in the Coastal Zone } \\ \text { MODIS } & \text { Moderate-resolution Imaging Spectroradiometer } \\ \text { NCEI } & \text { National Centers for Environmental Information } \\ \text { NCEP } & \text { National Centers for Environmental Prediction } \\ \text { NESDIS } & \text { National Environmental Satellite, Data, and Information Service } \\ \text { NOAA } & \text { National Oceanic and Atmospheric Administration } \\ \text { NH } & \text { North Hemisphere } \\ \text { PATMOS-x } & \text { Pathfinder Atmospheres-Extended } \\ \text { PBLH } & \text { planetary boundary layer height } \\ \text { PBL } & \text { planetary boundary layer } \\ \text { PW } & \text { precipitable water in atmospheric column } \\ \text { RH } & \text { relative humidity } \\ \text { SH } & \text { South Hemisphere } \\ \text { SON } & \text { September-October-November } \\ \text { TMP } & \text { surface temperature } \\ & \end{array}$

\section{References}

1. Lai, C.-C.; Shih, T.-P.; Ko, W.-C.; Tang, H.-J.; Hsueh, P.-R. Severe acute respiratory syndrome coronavirus 2 (SARS-CoV-2) and coronavirus disease-2019 (COVID-19): The epidemic and the challenges. Int. J. Antimicrob. Agents 2020, 55, 105924. [CrossRef]

2. Sohrabi, C.; Alsafi, Z.; O’Neill, N.; Khan, M.; Kerwan, A.; Al-Jabir, A.; Iosifidis, C.; Agha, R. World health organization declares global emergency: A review of the 2019 novel coronavirus (COVID-19). Int. J. Surg. 2020, 76, 71-76. [CrossRef] [PubMed]

3. Le, T.; Wang, Y.; Liu, L.; Yang, J.; Yung, Y.L.; Li, G.; Seinfeld, J.H. Unexpected air pollution with marked emission reductions during the COVID-19 outbreak in china. Science 2020, 369, 702-706. [CrossRef] [PubMed]

4. Nakada, L.Y.K.; Urban, R.C. COVID-19 pandemic: Impacts on the air quality during the partial lockdown in são paulo state, brazil. Sci. Total Environ. 2020, 730, 139087. [CrossRef] [PubMed]

5. Sharma, S.; Zhang, M.; Anshika; Gao, J.; Zhang, H.; Kota, S.H. Effect of restricted emissions during COVID-19 on air quality in india. Sci. Total Environ. 2020, 728, 138878. [CrossRef]

6. Amouei Torkmahalleh, M.; Akhmetvaliyeva, Z.; Omran, A.D.; Faezeh Darvish Omran, F.; Kazemitabar, M.; Naseri, M.; Naseri, M.; Sharifi, H.; Malekipirbazari, M.; Kwasi Adotey, E.; et al. Global air quality and COVID-19 pandemic: Do we breathe cleaner air? Aerosol Air Qual. Res. 2021, 21, 200567. [CrossRef]

7. Chen, Q.-X.; Huang, C.-L.; Yuan, Y.; Tan, H.-P. Influence of COVID-19 event on air quality and their association in mainland china. Aerosol Air Qual. Res. 2020, 20, 1541-1551. [CrossRef]

8. Chen, K.; Wang, M.; Huang, C.; Kinney, P.L.; Anastas, P.T. Air pollution reduction and mortality benefit during the COVID-19 outbreak in china. Lancet Planet. Health 2020, 4, e210-e212. [CrossRef]

9. Dantas, G.; Siciliano, B.; França, B.B.; da Silva, C.M.; Arbilla, G. The impact of COVID-19 partial lockdown on the air quality of the city of rio de janeiro, brazil. Sci. Total Environ. 2020, 729, 139085. [CrossRef] 
10. Lal, P.; Kumar, A.; Kumar, S.; Kumari, S.; Saikia, P.; Dayanandan, A.; Adhikari, D.; Khan, M.L. The dark cloud with a silver lining: Assessing the impact of the sars COVID-19 pandemic on the global environment. Sci. Total Environ. 2020, 732, 139297. [CrossRef]

11. Metya, A.; Dagupta, P.; Halder, S.; Chakraborty, S.; Tiwari, Y.K. COVID-19 lockdowns improve air quality in the south-east asian regions, as seen by the remote sensing satellites. Aerosol Air Qual. Res. 2020, 20, 1772-1782. [CrossRef]

12. Ranjan, A.K.; Patra, A.K.; Gorai, A.K. Effect of lockdown due to sars COVID-19 on aerosol optical depth (aod) over urban and mining regions in india. Sci. Total Environ. 2020, 745, 141024. [CrossRef]

13. Sannino, A.; D'Emilio, M.; Castellano, P.; Amoruso, S.; Boselli, A. Analysis of air quality during the COVID-19 pandemic lockdown in naples (italy). Aerosol Air Qual. Res. 2021, 21, 200381. [CrossRef]

14. Zhao, X. Impact of COVID-19 lockdowns and australian bushfires on aerosol loading over the downwind oceanic regions. Adv. Environ. Eng. Res. 2020, 1, 1. [CrossRef]

15. Mage, D.; Ozolins, G.; Peterson, P.; Webster, A.; Orthofer, R.; Vandeweerd, V.; Gwynne, M. Urban air pollution in megacities of the world. Atmos. Environ. 1996, 30, 681-686. [CrossRef]

16. Molina, M.J.; Molina, L.T. Megacities and atmospheric pollution. J. Air Waste Manag. 2004, 54, 644-680. [CrossRef]

17. Parrish, D.D.; Zhu, T. Clean air for megacities. Science 2009, 326, 674-675. [CrossRef]

18. Zhang, L.; Yang, L.; Zhou, Q.; Zhang, X.; Xing, W.; Zhang, H.; Toriba, A.; Hayakawa, K.; Tang, N. Impact of the COVID-19 outbreak on the long-range transport of particulate pahs in east asia. Aerosol Air Qual. Res. 2020, 20, 2035-2046. [CrossRef]

19. Zhao, X.P. Satellite observed aerosol optical thickness and trend around megacities in the coastal zone. Adv. Meteorol. 2015, 2015, 170672. [CrossRef]

20. von Glasow, R.; Jickells, T.D.; Baklanov, A.; Carmichael, G.R.; Church, T.M.; Gallardo, L.; Hughes, C.; Kanakidou, M.; Liss, P.S.; Mee, L.; et al. Megacities and large urban agglomerations in the coastal zone: Interactions between atmosphere, land, and marine ecosystems. Ambio 2013, 42, 13-28. [CrossRef] [PubMed]

21. Guttikunda, S.K.; Carmichael, G.R.; Calori, G.; Eck, C.; Woo, J.-H. The contribution of megacities to regional sulfur pollution in asia. Atmos. Environ. 2003, 37, 11-22. [CrossRef]

22. Kanakidou, M.; Mihalopoulos, N.; Kindap, T.; Im, U.; Vrekoussis, M.; Gerasopoulos, E.; Dermitzaki, E.; Unal, A.; Kocak, M.; Markakis, K.; et al. Megacities as hot spots of air pollution in the east mediterranean. Atmos. Environ. 2011, 45, 1223-1235. [CrossRef]

23. Gurjar, B.R.; Lelieveld, J. New directions: Megacities and global change. Atmos. Environ. 2005, 39, 391-393. [CrossRef]

24. Lawrence, M.G.; Lelieveld, J. Atmospheric pollutant outflow from southern asia: A review. Atmos. Chem. Phys. 2010, 10, 11017-11096. [CrossRef]

25. Ramanathan, V.; Crutzen, P.J.; Kiehl, J.T.; Rosenfeld, D. Atmosphere-Aerosols, climate, and the hydrological cycle. Science 2001, 294, 2119-2124. [CrossRef]

26. Charlson, R.J.; Schwartz, S.E.; Hales, J.M.; Cess, R.D.; Coakley, J.A.; Hansen, J.E.; Hofmann, D.J. Climate forcing by anthropogenic aerosols. Science 1992, 255, 423-430. [CrossRef]

27. Kaufman, Y.J.; Koren, I.; Remer, L.A.; Rosenfeld, D.; Rudich, Y. The effect of smoke, dust, and pollution aerosol on shallow cloud development over the atlantic ocean. Proc. Natl. Acad. Sci. USA 2005, 102, 11207-11212. [CrossRef] [PubMed]

28. Whitehead, J.D.; McFiggans, G.; Gallagher, M.W.; Flynn, M.J. Simultaneous coastal measurements of ozone deposition fluxes and iodine-mediated particle emission fluxes with subsequent ccn formation. Atmos. Chem. Phys. 2010, 10, 255-266. [CrossRef]

29. Kumar, N.; Chu, A.; Foster, A. An empirical relationship between pm(2.5) and aerosol optical depth in delhi metropolitan. Atmos. Environ. 2007, 41, 4492-4503. [CrossRef]

30. Lin, C.; Li, Y.; Yuan, Z.; Lau, A.; Li, C.; Fung, J. Using satellite remote sensing data to estimate the high-resolution distribution of ground-level $\mathrm{PM}_{2.5}$. Remote Sens. Environ. 2015, 156, 117-128. [CrossRef]

31. Zheng, C.; Zhao, C.; Zhu, Y.; Wang, Y.; Shi, X.; Wu, X.; Chen, T.; Wu, F.; Qiu, Y. Analysis of influential factors for the relationship between $\mathrm{PM}_{2.5}$ and aod in beijing. Atmos. Chem. Phys. 2017, 17, 13473-13489. [CrossRef]

32. Kumari, S.; Lakhani, A.; Kumari, K.M. COVID-19 and air pollution in indian cities: World's most polluted cities. Aerosol Air Qual. Res. 2020, 20, 2592-2603. [CrossRef]

33. Sipra, H.; Aslam, F.; Syed, J.H.; Awan, T.M. Investigating the implications of COVID-19 on PM 2.5 in pakistan. Aerosol Air Qual. Res. 2021, 21, 200459. [CrossRef]

34. Ibrahim, R.L.; Ajide, K.B.; Olatunde Julius, O. Easing of lockdown measures in nigeria: Implications for the healthcare system. Health Policy Technol. 2020, 9, 399-404. [CrossRef] [PubMed]

35. Zhao, X.-P.; Dubovik, O.; Smirnov, A.; Holben, B.N.; Sapper, J.; Pietras, C.; Voss, K.J.; Frouin, R. Regional evaluation of an advanced very high resolution radiometer (avhrr) two-channel aerosol retrieval algorithm. J. Geophys. Res. 2004, 109, D02204. [CrossRef]

36. Heidinger, A.K.; Foster, M.J.; Walther, A.; Zhao, X.P. The pathfinder atmospheres-extended avhrr climate dataset. Bull. Am. Meteorol. Soc. 2014, 95, 909-922. [CrossRef]

37. Zhao, X.-P.; Laszlo, I.; Holben, B.N.; Pietras, C.; Voss, K.J. Validation of two-channel virs retrievals of aerosol optical thickness over ocean and quantitative evaluation of the impact from potential subpixel cloud contamination and surface wind effect. J. Geophys. Res.-Atmos. 2003, 108, 4106. [CrossRef] 
38. Zhao, X.-P.; Laszlo, I.; Minnis, P.; Remer, L. Comparison and analysis of two aerosol retrievals over the ocean in the terra/clouds and the earth's radiant energy system-Moderate resolution imaging spectroradiometer single scanner footprint data: 1 . Global evaluation. J. Geophys. Res.-Atmos. 2005, 110, D21208. [CrossRef]

39. Saha, S.; Moorthi, S.; Pan, H.L.; Wu, X.R.; Wang, J.D.; Nadiga, S.; Tripp, P.; Kistler, R.; Woollen, J.; Behringer, D.; et al. The ncep climate forecast system reanalysis. Bull. Am. Meteorol. Soc. 2010, 91, 1015-1057. [CrossRef]

40. Praveena, S.M.; Aris, A.Z. The impacts of COVID-19 on the environmental sustainability: A perspective from the southeast asian region. Environ. Sci. Pollut Res. 2021, 28, 63829-63836. [CrossRef] [PubMed]

41. Li, Z.; Lau, W.K.-M.; Ramanathan, V.; Wu, G.; Ding, Y.; Manoj, M.G.; Liu, J.; Qian, Y.; Li, J.; Zhou, T.; et al. Aerosol and monsoon climate interactions over asia. Rev. Geophys. 2016, 54, 866-929. [CrossRef]

42. Park, S.-B.; Cho, J.-A.; Park, S.S.; Koo, J.-H.; Lee, Y.G. A possible linkage between dust frequency and the siberian high in march over northeast asia. Atmosphere 2021, 12, 176. [CrossRef]

43. Xia, X.; Che, H.; Zhu, J.; Chen, H.; Cong, Z.; Deng, X.; Fan, X.; Fu, Y.; Goloub, P.; Jiang, H.; et al. Ground-based remote sensing of aerosol climatology in china: Aerosol optical properties, direct radiative effect and its parameterization. Atmos. Environ. 2016, 124, 243-251. [CrossRef]

44. Hu, Z.; Huang, J.; Zhao, C.; Ma, Y.; Jin, Q.; Qian, Y.; Leung, L.R.; Bi, J.; Ma, J. Trans-pacific transport and evolution of aerosols: Spatiotemporal characteristics and source contributions. Atmos. Chem. Phys. 2019, 19, 12709-12730. [CrossRef]

45. Sun, J.; Zhang, M.; Liu, T. Spatial and temporal characteristics of dust storms in china and its surrounding regions, 1960-1999: Relations to source area and climate. J. Geophys. Res. Atmos. 2001, 106, 10325-10333. [CrossRef] 